\section{Pear-Apple Hybrids}

AT the John Innes Horticultural Institution we have recently raised hybrids between pears and apples; they were obtained in the following way. The occurrence of apomixis in the Pomoider ${ }^{1}$, and the high frequency of diploid seedlings, 23 out of 39 , in a family of pears we raised from crossing the diploid variety Fertility with the triploid variety the hybrids on to apple seedlings, it appears that difficulty in growth may be overcome.

One seedling in each family has been examined cytologically by Mr. R. D. Brock: the one in which the tetraploid apple was the male parent was triploid and the one with the diploid apple parent was diploid. This supports their hybridity.

In the past we have made pollinations between apples and pears but never obtained seeds. They were made without any hormone treatment, and it therefore seems that, when distant crosses with plants are being attempted, the use of $\beta$-naphthoxy-acetic acid may be of value.

It appears that this is the first time sexual hybrids between pears and apples have been produced. In Plant Breeding Extracts ${ }^{2}$, an apple-pear hybrid is referred to in Sweden, at the Balsgård Fruit Breeding Institute; but Dr. I. Granhall, director of the Institute, has recently informed us that this is wrong and that no such hybrid is known in Sweden. According to Dr. Granhall, this false report originally appeared in a newspaper article. The alleged apple-pear vegetative hybrid Reinette-Bergamotte, referred to so much in recent years by Soviet scientific men, is figured, and an account of it given, in Michurin's "Selected

Works". From the illustrations

(a) Pear; (b) surviving pear-apple hybrid; (c) dying par-apple hybrid ; $(d)$ apple and the descriptive account of Reinette-Bergamotte,
it appears to us to bo entirely apple.

M. B. Crane

E. Marks

John Innes Horticultural Institution,

Bayfordbury; Hertford.

Oct. 24.

of $\beta$-naphthoxy-acetic acid. Four flowers were pollinated with the pollen of an unnamed tetraploid variety of apple and twelve with the pollen of the diploid apple Crawley Beauty. Twenty-four hours later the ovaries were again treated with $\beta$-naphthoxyacetic acid. Three fruits developed from pollination with the tetraploid apple and twelve from pollination with the diploid. Seed content and germination are shown in the following table.

\begin{tabular}{|c|c|c|c|c|c|c|c|}
\hline Pear & Fertility $2 x$ & Flowers & Fruit & Seeds & $\begin{array}{l}\text { Seeds } \\
\text { sown }\end{array}$ & $\begin{array}{c}\text { Germ- } \\
\text { inated }\end{array}$ & $\begin{array}{c}\text { Sur- } \\
\text { vived }\end{array}$ \\
\hline$\times$ & Apple 4x & 4 & 3 & 13 & 18 & 13 & 1 \\
$\times$ & Apple 2x & 12 & 12 & 100 & 79 & 56 & 10 \\
\hline
\end{tabular}

During the early stages of growth the seedlings were very uniform, and at first we thought they were pears of apomictic origin. Later their development was unusual, and it became clear that the plants were not pear seedlings but pear-apple hybrids. They developed intermediate characters, and after three months showed slightly greater resemblance to the male apple parent, though distinct from normal apple. Furthermore, all the seedlings had a somewhat defective root development and appeared to lack ability to take up sufficient of some of the essential mineral nutrients. In consequence, many of the seedlings died, but eleven have survived (see table and photograph). From preliminary grafting of some of ${ }^{1}$ Dermen, H., J. Arnold Arbor., 17, 90 (1936); J. Hered., 40, 162
(1949). Sax, K., Proc. Amer. Soc. Hort. Sci., 53, 219 (1949). ${ }^{2}$ Plant Breeding Abst., 22, No. 658, 125 (1952).

${ }^{3}$ Michurin, I. V., "Selected Works" (Collet's, London, 1949).

\section{Rate of Photosynthesis and Concentration of Carbon Dioxide in Chlorella}

Previous investigations of the relationship in Chlorella between rate of photosynthesis at high light intensities and concentration of carbon dioxide have been made using cells suspended in alkaline solutions $^{1}$. In such solutions cells grown in 4 per cent carbon dioxide show an unusually long induction phase $\left(t_{1 / 2}, 40-50 \mathrm{~min}\right.$.) at low concentrations of carbon dioxide; but when allowance is made for this and the rate of photosynthesis in the steady state alone considered, half the maximum rate is attained with a concentration of carbon dioxide ${ }^{2}$ of $0.9 \times$ $10^{-6} \mathrm{M}$ at $25^{\circ} \mathrm{C}$. The possibility has been suggested that in alkaline solution the relatively high concentration of bicarbonate ion affects the rate of photosynthesis ${ }^{3}$.

Experiments have now been made with Chlorella pyrenoidosa in acid phosphate solution ( $M / 30$ potassium dihydrogen phosphate, $p H$ 4.6). The cell suspension was placed in a tube containing a sintered glass bubbler which was connected in a closed circuit with appropriate drying tubes and with one absorption 